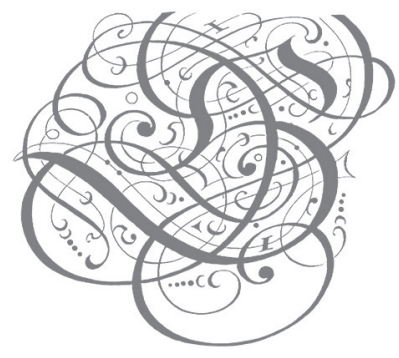

\title{
ENHANCING ACCESS TO HIGHER EDUCATION THROUGH UNIVERSITY- GOVERNMENT COOPERATION (THE CASE OF RUSSIAN FAR EAST REGIONS)
}

\author{
T. N. Blinova ${ }^{a}$, A. V. Fedotov ${ }^{b}$ \\ ${ }^{a}$ Far East Institute of Management (Branch of RANEPA) \\ 33 Muravyev Amur str., Khabarovsk, 680000, Russian Federation; \\ Blinova-82@rambler.ru \\ ${ }^{b}$ Russian Presidential Academy of National Economy and Public Administration (RANEPA) \\ 82 Vernadskogo ave., Moscow, 119571, Russian Federation
}

\begin{abstract}
This article discusses issues associated with the facilitation of higher education accessibility by intensifying university-government cooperation. Existing approaches to measuring the accessibility of the higher education system as a whole and its specific components were analysed. Various aspects of the problem were investigated using the example of higher education institutions in the Russian Far East. The analysis was based on data retrieved from the Russian Federal Statistics Service and the Unified Information System of the Ministry of Education and Science. It is shown that residents in the Russian Far East receive substantial opportunities for accessing higher education as compared to the residents in other Russian federal districts. Nevertheless, the extremely low geographical accessibility of higher education in this part of Russia has a detrimental effect on overall access to higher education. On the basis of the obtained results, a number of recommendations were developed for facilitating cooperation between universities and governmental authorities in order to increase overall accessibility to higher education in this region. It is proposed to compensate for the negative impact of the geographical factor by maximizing the positive effects of other factors, for instance, by increasing the affordability of university education. Thus, students from locations with absent or very few higher education institutions may be reimbursed for their travel expenses, or reimbursement may be offered to those students who are not provided with dormitory accommodation. Universities may keep their tuition fees at the lowest rate as established by the RF legislation. Keywords: higher education, availability, affordability, geographic accessibility, access to higher education, assessment methodology, regions, university policy, university-government interaction

For citation: Blinova T. N., Fedotov A. V. Enhancing Access to Higher Education through University-Government Cooperation (the Case of Russian Far Eastern Regions). University Management: Practice and Analysis. 2019; 23(5): 12-21. DOI: 10.15826/umpa.2019.05.037
\end{abstract}

\section{Introduction}

Contemporary socio-economic development strategies require countries to ensure equal access to higher education for their citizens, resulting in the need for national governments to assign a high priority to the implementation of these policies [1, 2]. In Russia, the legal right to education is enshrined in Paragraph 3 Article 5 of the Federal Law On Education in the Russian Federation ${ }^{1}$. This right is also upheld by the state program Development of Education for

${ }^{1}$ On Education in the Russian Federation: Federal Law of 29.12.2012. № 273-FZ. Accessed via the legal reference system 'ConsultantPlus'
2013-20202, which describes measures aimed at enhancing access to education in the country. The national project Education ${ }^{3}$ (for the period 2019-2024) comprises a set of institutional mechanisms to expand access to education and create opportunities for individual development within the system of education. It is

${ }^{2}$ State Program of the Russian Federation 'Development of Education' for 2013-2020: Decree of the Government of the Russian Federation of 15.05.2013 № 792p. Accessed via the legal reference system 'ConsultantPlus'.

${ }^{3}$ Passport of the national project 'Education' approved by the Presidium of the Presidential Council for Strategic Development and National Projects (Minutes of 24 December 2018, № 16). Accessed via the legal reference system 'ConsultantPlus'. 
declared that one of the priorities of the state education policy is 'to ensure equal access to education for all Russian citizens regardless of their region of residence'.

Russian regions vary significantly in terms of size, level of economic development, number of universities and other parameters. All these factors affect the level of higher education accessibility in various regions. The Far East is the largest federal district in Russia. In many of its parts, universities or their branches are located only in regional centres, making education less accessible to the inhabitants of small towns and rural areas. In comparison with other federal districts, the Far East is characterized by a low level of economic development, which affects the affordability of higher education. Therefore, a detailed analysis of higher education accessibility and factors determining its level should be carried out in order to develop respective regional and federal strategies. The role of universities in this process cannot be overestimated: working together with government agencies and taking part in decision making and strategy implementation, universities can have a tremendous social and economic impact [3].

\section{Methodological framework}

Approaches currently applied to measure access to higher education can be broadly classified into four groups: equal opportunities, compilation, structural and probability-based approaches (Table 1).

Approaches to measuring access to higher education

\begin{tabular}{|c|c|c|c|c|}
\hline Approaches & $\begin{array}{l}\text { Definition of access to } \\
\text { higher education }\end{array}$ & $\begin{array}{l}\text { Components of the integral } \\
\text { indicator }\end{array}$ & $\begin{array}{l}\text { Integral indicator calcula- } \\
\text { tion methods }\end{array}$ & Authors \\
\hline $\begin{array}{l}\text { Equal opportu- } \\
\text { nities approach }\end{array}$ & $\begin{array}{l}\text { Access to higher education } \\
\text { means equal opportunities } \\
\text { for prospective students to } \\
\text { be enrolled at university }\end{array}$ & $\begin{array}{l}\text { Participation of young } \\
\text { people in higher educa- } \\
\text { tion; youth education } \\
\text { attainment level; index } \\
\text { of social equality; index } \\
\text { of gender parity [4]. Who } \\
\text { should access and partici- } \\
\text { pate in higher education? } \\
\text { Are the university admis- } \\
\text { sion practices fair? [5] }\end{array}$ & $\begin{array}{l}\text { Youth participation in } \\
\text { higher education* } 0.25+ \\
\text { youth education attain- } \\
\text { ment level* } 0.25+\text { index of } \\
\text { social equality*0.4+ index } \\
\text { of gender parity* } 0.1 \text { [ } 4]\end{array}$ & $\begin{array}{l}\text { Global Higher Educa- } \\
\text { tion Rankings project [4], } \\
\text { OECD Directorate for } \\
\text { Education and Skills [5], } \\
\text { A. S. Klyuev [6], T. P. Evs- } \\
\text { eenko [7], V. I. Fursova [8], } \\
\text { and Ha Vang Hoang [9] }\end{array}$ \\
\hline $\begin{array}{l}\text { Compilation } \\
\text { approach }\end{array}$ & $\begin{array}{l}\text { Access to higher education } \\
\text { is determined by a set of } \\
\text { external factors affect- } \\
\text { ing the system of higher } \\
\text { education }\end{array}$ & $\begin{array}{l}\text { Matching university's } \\
\text { specialization to the prior- } \\
\text { ity directions of regional } \\
\text { development; the number } \\
\text { of educational programs } \\
\text { implemented at a univer- } \\
\text { sity; the share of Master's } \\
\text { students in the total num- } \\
\text { ber of students enrolled at } \\
\text { a university; the share of } \\
\text { university graduates work- } \\
\text { ing in the fields related to } \\
\text { their degrees [10] }\end{array}$ & $\begin{array}{l}\text { Access to higher education } \\
\text { is calculated as a sum of } \\
\text { constituent indicators [10] }\end{array}$ & $\begin{array}{l}\text { V. I. Sukhochev [11], } \\
\text { M. S. Rakhmanova [10] }\end{array}$ \\
\hline $\begin{array}{l}\text { Structural ap- } \\
\text { proach }\end{array}$ & $\begin{array}{l}\text { Access to higher education } \\
\text { is determined by a set of } \\
\text { internal factors affect- } \\
\text { ing the system of higher } \\
\text { education }\end{array}$ & $\begin{array}{l}\text { Equal access to leading } \\
\text { universities for all citizens } \\
\text { of any socio-economic } \\
\text { status; equal opportunities } \\
\text { to participate in entrance } \\
\text { examinations and edu- } \\
\text { cational programs; equal } \\
\text { access to intellectual } \\
\text { resources [12] }\end{array}$ & $\begin{array}{l}\text { This approach does not of- } \\
\text { fer an integral indicator to } \\
\text { measure access to higher } \\
\text { education. }\end{array}$ & $\begin{array}{l}\text { E. A. Anikina, E. V. La- } \\
\text { zarchuk, V. I. Kly- } \\
\text { achko [13] }\end{array}$ \\
\hline $\begin{array}{l}\text { Probability- } \\
\text { based ap- } \\
\text { proach }\end{array}$ & $\begin{array}{l}\text { Access as the likelihood } \\
\text { of a student to attend uni- } \\
\text { versity and obtain higher } \\
\text { education }\end{array}$ & $\begin{array}{l}\text { The number of students } \\
\text { enrolled at a university; } \\
\text { the number of admission } \\
\text { applications }\end{array}$ & $\begin{array}{l}\mathrm{A}=\mathrm{SE} / \mathrm{AA} \text {, where } \mathrm{A} \text { is } \\
\text { access to higher educa- } \\
\text { tion; } \mathrm{SE} \text { is the number of } \\
\text { students enrolled; and AA } \\
\text { is the number of admis- } \\
\text { sion applications [14]. }\end{array}$ & $\begin{array}{l}\text { Y. M. Roschina [15], } \\
\text { S. A. Belyakov [14] }\end{array}$ \\
\hline
\end{tabular}

Source: compiled from [4-15]. 
There is no generally agreed definition as to what exactly constitutes access to higher education. Some definitions fail to make a distinction between access to higher education and higher education attainment; some focus on prospective students rather than on the education system, which raises the question of quantitative measurement. We believe that the definition proposed by S. A. Belyakov is the most appropriate for the purposes of our research: this model defines access to higher education as the likelihood of students to be enrolled at higher education institutions [14].

Russian and international studies use diverse methods to measure access to higher education, which makes the question of their validity particularly relevant.

There are at least two methodologies worthy of attention proposed by international research groups: Canadian researchers from the Global Higher Education Rankings project [4] and the OECD Directorate for Education and Skills [5]. These methodologies are both used for comparative analysis: the former served to develop a ranking of countries according to the affordability and accessibility of higher education based on four indicators with their own weights (Table 1). In our view, however, these indicators reflect only social aspects of the problem (that is, the opportunities of obtaining higher education enjoyed by particular social groups) and fail to provide a wider picture. The latter methodology offers a more general approach to the problem and includes several indicators. Nevertheless, both these methodologies focus exclusively on access to higher education for specific social categories, which makes them rather limited $[11,12,16]$.

In Russia, one of the first methodologies was proposed by S. A. Belyakov in the early 2000s [14]. The researcher suggested measuring access to higher education by dividing the number of students enrolled at universities by the number of admission applications, which reflects the likelihood for a student to attain higher education. A certain limitation of this methodology (though not diminishing its practical value) is that students' right to apply to several universities is not taken into account. This means that the results obtained using this approach should be additionally analysed. Therefore, Belyakov's approach is suitable for assessing access to higher education.

In the 2000s, S. A. Rakhmanova [10] developed a methodology for measuring access to higher education services provided by universities engaged in the implementation of developmental programs. Her methodology relies on the indicators used to monitor the efficiency of such universities and the data included in their reports about the progress of these programs. Thus, her methodology is suitable only when the research focus is on studying specific universities rather than the higher education system in large regions or countries.

Access to higher education encompasses several dimensions, in particular availability, affordability, social accessibility, educational (in)equality and inclusion. Let us look at the components and factors determining their status in greater detail.

The majority of Russian and international scholars distinguish the following key components of access to higher education (factors that determine access to higher education or lack thereof):

- geographical accessibility (geographical factor), i. e. access to higher education depending on the distance a prospective student has to travel to reach the university [16-20];

- affordability (economic or financial factor), i.e. the cost of higher education and financial resources available to students and their families [16, 21]

- social accessibility (social factor), that is, access to higher education for specific social groups [22-31];

- admission capacity and state support (organization factor), i. e. the number of enrolled students fully supported by the federal budget, availability of oncampus dormitory accommodation, etc. [11];

- educational (in)equality (education factor), i.e. the achievement gap or disparity in academic outcomes of students with different educational backgrounds, in particular, their Unified State Exam or university entrance exams scores[12, 19];

-inclusion (access to higher education for students with disabilities), i.e. opportunities provided for impaired students to access and participate in higher education $[12,19]$.

Let us consider the methods that we used to measure the specific aspects of access to higher education based on the data of the Far Eastern regions in Russia. It should be noted that social accessibility of education is not considered in this study, since its quantitative assessment requires large amounts of heterogeneous data, which, in turn, requires large-scale sociological surveys.

Geographical accessibility was estimated by considering the weighted average distance that each potential student has to cover in order to reach any institution of higher education located within the borders of the federal district. The weighted average distance was calculated using data on the distances between regional centres and universities (or their branches) located within the federal district. Thus, the average distance can be calculated both for the federal district as a whole and its regions. In order to take into account the uneven population distribution across the territory, we used the population-weighted average 
distance. The population under consideration consisted of young adults aged 18-30 living in a specific region or federal district.

Therefore, the geographical accessibility of higher education services can be calculated using the following formula:

\section{$\mathrm{GA}=\mathrm{Dmax} / \mathrm{D}$,}

where GA is the geographical accessibility of higher education;

Dmax is the maximum population-weighted average distance from a regional centre to a university in a federal district (by the 'population' here we mean young adults aged 18-30 living in the region);

$\mathrm{D}$ is the population-weighted average distance from a regional centre to a university in a federal district (by the 'population' here we mean young adults aged 18-30 living in the region).

In order to avoid uncertainty (division by zero) in cases where a university or its branches are located in a regional centre, we used the indicator of geographical inaccessibility of higher education, the opposite of geographical accessibility:

\section{$\mathrm{GIA}=\mathrm{D} / \mathrm{Dmax}$,}

where GIA is the geographical inaccessibility of higher education.

According to the above-described formula, the geographical inaccessibility of higher education for the inhabitants of a city with its own university will be 0 , while the maximum availability in this case will equal 1. On the contrary, for the inhabitants of remote areas, the inaccessibility and accessibility of higher education will be 1 and 0 , respectively. Higher education geographical inaccessibility can vary between 0 and 1 . The higher this indicator is, the less access to higher education people in this region will enjoy.

When we applied this methodology to measure the geographical inaccessibility of higher education in the Far East of Russia, we found that the impact of the geographical factor is particularly significant in the Jewish Autonomous District and Chukotka. This situation, to a great extent, results from the trend to concentrate universities in regional capitals, which leads to an increase in the parameter 'population-weighted average distance from a regional centre to a university in the Far Eastern Federal District'. On the contrary, the geographical accessibility is higher for inhabitants of Sakha and Zabaikalye. This can be explained by the concentration of young people in the cities, where universities are located. In other regions, the geographical inaccessibility of higher education remains practically at the same level.

It should be noted that, according to the Higher School of Economics research [16], all Far Eastern regions are characterized by the lowest level of geographical accessibility of higher education (except for Primorye) among other Russian regions. For instance,

Geographical inaccessibility of higher education in Far Eastern regions

Table 2

\begin{tabular}{|l|c|c|c|}
\hline \multicolumn{1}{|c|}{ Regions } & $\begin{array}{c}\text { Population-weighted average } \\
\text { distance from a regional centre } \\
\text { to universities, km (D) }\end{array}$ & $\begin{array}{c}\text { Maximum population-weighted } \\
\text { average distance from a re- } \\
\text { gional centre to universities, } \\
\text { km (Dmax) }\end{array}$ & $\begin{array}{c}\text { Geographical inaccessibility } \\
\text { of higher education (GIA) }\end{array}$ \\
\hline Republic of Sakha (Yakutia) & 65.5 & 946.9 & 0.069 \\
Kamchatka & 230.3 & 1809.3 & 0.127 \\
Primorye & 50.6 & 625.5 & 0.081 \\
Khabarovsk region & 92.7 & 915.3 & 0.101 \\
Amur region & 71.3 & 629.6 & 0.113 \\
Magadan region & 378.5 & 2478.7 & 0.153 \\
Sakhalin & 135.5 & 1118.8 & 0.121 \\
Jewish Autonomous District & 306.3 & 810 & 0.378 \\
Chukotka Autonomous District & 503.3 & 2124.3 & 0.237 \\
Zabaikalye & 74.9 & 1113.4 & 0.067 \\
Republic of Buryatia & 127.3 & 1206.8 & 0.105 \\
Average for the Far Eastern & 185.1 & 1252.6 & 0.148 \\
Federal District & & & \\
\hline
\end{tabular}

Source: compiled by the authors 
6 out of 11 Far Eastern regions ranked at the bottom of the list of 79 Russian regions. While the average level of this indicator for Russia equals $107 \mathrm{~km}$, most Far Eastern regions exceed this value by more than twice.

In order to measure affordability of higher education, we extended the approach proposed by A. D. Gromov, D. P. Platonova, D. S. Semenov and T. L. Pyrova [16]. This methodology distinguishes between the costs of higher education for federally-funded and tuition-paying students.

For tuition-paying students, the costs of higher education was calculated as follows:

$$
\mathrm{HEC}=\mathrm{TF}+\mathrm{RC} * \mathrm{OCS}+\mathrm{LE},
$$

where HEC is the annual cost of higher education;

$\mathrm{TF}$ is the average tuition fee per year in the region;

$\mathrm{RC}$ is the average rental cost of a single-room apartment per year in the region;

OCS is the share of students living off-campus in the total number of students in need of accommodation; region.

LE is the average living expenses per year in the

For federally-funded students, the following formula was used:

$$
\mathrm{HEC}=\mathrm{RC} * \mathrm{OCS}+\mathrm{LE}
$$

Expenses on higher education among the inhabitants of a certain region were calculated as the average costs of studying in any region of the federal district.

Therefore, let us introduce the indicator of inaffordability of higher education in a region, which can be calculated using the following formula:

$$
\mathrm{IHE}=\mathrm{HEC} / \mathrm{PCI},
$$

where IHE is the level of inaffordability of higher education;

PCI is the average annual per capita income in a region;

HEC is the annual cost of higher education.

According to the above-described approach, in case of zero spending on higher education, the inaffordability of higher education will equal zero (the maximum level of affordability) and, vice versa, if the spending on education exceeds the average annual per capita income, the inaffordability will exceed 1 .

Theoretically, this indicator of inaffordability of higher education can vary from zero to infinity. The higher the annual per capita income (with equal spending on higher education), the higher is the affordability of education. Vice versa (and quite predictably), the higher the spending (with equal per capita income), the lower the affordability of higher education. Nevertheless, the upper limit for the inaffordability indicator is set by the state system of economic mechanisms, such as subsistence rates, the amount of public funds spent on education; subsidized education loan rates and so on.

Table 3 shows that higher education is not substantially affordable for residents in Zabaikalye, Jewish Autonomous District and Buryatia due to the low level of economic development and per capita income in these locations. It should be noted that the average costs of higher education in Zabaikalye and the Jewish Autonomous District exceed the average annual income level of their populations. Not surprisingly, the high level of higher education affordability in Chukotka correlates with high incomes in the region.

Table 3

\begin{tabular}{|c|c|c|}
\hline \multirow{2}{*}{ Regions } & \multicolumn{2}{|c|}{$\begin{array}{c}\text { Inaffordability of higher educa- } \\
\text { tion (IHE) }\end{array}$} \\
\hline & $\begin{array}{l}\text { federally- } \\
\text { funded }\end{array}$ & $\begin{array}{l}\text { tuition- } \\
\text { paying }\end{array}$ \\
\hline Zabaikalye & 0.709 & 1.065 \\
\hline Jewish Autonomous District & 0.695 & 1.045 \\
\hline Republic of Buryatia & 0.659 & 0.990 \\
\hline Amur region & 0.556 & 0.836 \\
\hline Primorye & 0.508 & 0.764 \\
\hline Far Eastern Federal District & 0.481 & 0.724 \\
\hline Khabarovsk region & 0.440 & 0.662 \\
\hline Republic of Sakha (Yakutia) & 0.424 & 0.636 \\
\hline Kamchatka & 0.402 & 0.604 \\
\hline Sakhalin & 0.332 & 0.500 \\
\hline Magadan region & 0.313 & 0.470 \\
\hline $\begin{array}{l}\text { Chukotka Autonomous } \\
\text { District }\end{array}$ & 0.258 & 0.388 \\
\hline
\end{tabular}

\section{Inaffordability of higher education in Far Eastern regions}

Source: compiled by the authors on the basis of Internet data

Similar to the above-described approach used to measure higher education geographical accessibility and affordability, we used the indicator of educational inequality to describe the barriers preventing students from being admitted to the university when their exam scores are lower than the average level in a federal district. This indicator was calculated according to the following formula:

\section{$\mathrm{IE}=\mathrm{EXAMact} / \mathrm{EXAMav}$,}

where IE is the inequality in the sphere of higher education; 
EXAMact is the average score in the Unified State Exam and university entrance exams of applicants to higher education institutions in a specific region;

EXAMav is the average score in the Unified State Exam and university entrance exams in a federal district.

According to this formula, the lower the average Unified State Exam score for students admitted to universities, the higher the education equality (and vice versa).

As Table 4 shows, Sakhalin, Magadan, and Zabaikalye are characterized by low levels of education inequality, which can be partially explained by the fact that these regions feature few universities specializing in arts and sports and, therefore, few universities have the right to organize their own entrance examinations (as a rule, the average admission score in such universities is much higher than the average Unified State Exam score). In Khabarovsk region and Chukotka, the level of education inequality is quite high.

The role of state support and admission capacity in providing access to higher education is mostly described by the number of undergraduate enrolment spots. Every university has its own target admission figures including the number of government-funded students, while the number of tuition-paying students is determined indirectly by other factors such as licensing and accreditation standards. Therefore, a university's admission capacity is a significant factor, which determines its accessibility through a limited number of places (federally funded and tuition-based) allocated to universities (by who?).

The impact of this factor can be measured similarly to that of higher education affordability. For federally-funded students, the following formula was used to measure the lack of access to higher education due to the shortage of federally-funded places:

$$
\mathrm{LAC}(\mathrm{sf})=\mathrm{A}(\mathrm{sf}) / \mathrm{N}(\mathrm{sf}) \text {, }
$$

where LAC(sf) is the lack of access to education determined by a university' admission capacity;

$\mathrm{A}(\mathrm{sf})$ is the number of applications for admission to federally-funded places;

$\mathrm{N}(\mathrm{sf})$ is the number of available federally-funded places.

For tuition-paying students, the formula takes the following form:

$$
\mathrm{LAC}(\mathrm{fp})=\mathrm{A}(\mathrm{fp}) / \mathrm{N}(\mathrm{fp}) \text {, }
$$

where LA(fp) is the lack of access to education due to the shortage of tuition-paying places;

$A(f p)$ is the number of applications for admission to tuition-paying places;

$\mathrm{N}(\mathrm{fp})$ is the number of available tuition-paying places.

When the number of available places exceeds that of applications, access to higher education is considered to be maximal at this university. The less

Educational inequality in Far Eastern regions

\begin{tabular}{|c|c|c|c|}
\hline Regions & $\begin{array}{l}\text { Average exam score for } \\
\text { admission to universities } \\
\text { in the region }\end{array}$ & $\begin{array}{l}\text { Average exam score for } \\
\text { admission to universities } \\
\text { in the federal district }\end{array}$ & Educational inequality (IE) \\
\hline Sakhalin & 54.25 & \multirow{12}{*}{58.25} & 0.931 \\
\hline Zabaikalye & 55.92 & & 0.960 \\
\hline Magadan region & 56.3 & & 0.967 \\
\hline Primorye & 56.7 & & 0.973 \\
\hline Jewish Autonomous District & 56.92 & & 0.977 \\
\hline Republic of Buryatia & 57.17 & & 0.981 \\
\hline Kamchatka & 57.29 & & 0.984 \\
\hline Republic of Sakha (Yakutia) & 57.88 & & 0.994 \\
\hline Amur region & 58.14 & & 0.998 \\
\hline Far Eastern Federal District & 58.63 & & 1 \\
\hline Khabarovsk region & 62.88 & & 1.079 \\
\hline Chukotka Autonomous District & 67.27 & & 1.155 \\
\hline
\end{tabular}

Table 4

Source: compiled by the authors on the basis of the data retrieved from https://indicators.miccedu.ru/ 
applications a university receives, the more available places it has; vice versa, the more applications it receives, the more selective it becomes.

We found that the Khabarovsk and Primorye regions suffer from the most severe shortage of study places, which can be partially explained by the fact that universities in these regions are quite attractive for prospective students from other Russian regions. As a result, the indicator 'number of applications' grows, thus impeding access to higher education. Chukotka shows the highest level in terms of admission capacity, particularly for federally-funded places: almost every second student accepted to university is enrolled in a federally-funded programme. The Kamchatka and Amur regions, as well as the Jewish Autonomous District and Buryatia, demonstrate high levels of higher education accessibility in terms of the availability of undergraduate places for tuition-paying students. In these regions, the number of tuition-paying places exceeds that of applications (see Table 5).

Having documented four components describing access to higher education, let us turn to calculation of an integral indicator.

It would be logical to assume that the above-mentioned factors play different roles in the overall access (or lack thereof) of higher education. Our survey, which covered 400 students in a Far Eastern university during the academic year of 2019-2020, showed the weight of each of these factors. The respondents considered the availability of enrolment places as the most significant factor (0.29), while the geographical access to university was shown to be the least significant (0.2). The affordability and equal opportunities in admissions were deemed almost equally important0.26 and 0.25 , respectively.

We used the results of the survey to draw the following formula for the integral indicator of the lack of access to higher education (LA):

$$
\mathrm{LA}=0.2 * \mathrm{GIA}+0.26 * \mathrm{IHE}+0.25 * \mathrm{IE}+0.29 * \mathrm{LAC} \text {, }
$$

where LA is the lack of access to higher education.

Access to higher education is the indicator opposite to the lack of access to higher education. Therefore, it can be calculated using the following formula:

$$
\mathrm{A}=1 / \mathrm{LA} \text {, }
$$

where $\mathrm{A}$ is access to higher education.

Integral indicators calculated for the Far Eastern federal district and its regions are shown in Table 6.

Access to higher education in different regions varies depending on the type of funding, i.e., whether the funds come from government subsidies or students' tuition.

In terms of federally-funded places, the lowest results are shown by the three regions-Zabaikalye,

\begin{tabular}{|c|c|c|c|c|c|c|}
\hline \multirow{2}{*}{ Regions } & \multicolumn{2}{|c|}{ Number of places } & \multicolumn{2}{|c|}{$\begin{array}{c}\text { Number of admission applica- } \\
\text { tions }\end{array}$} & \multicolumn{2}{|c|}{$\begin{array}{l}\text { Lack of access to higher educa- } \\
\text { tion due to the shortage of places }\end{array}$} \\
\hline & $\begin{array}{l}\text { federally- } \\
\text { funded }\end{array}$ & tuition-paying & $\begin{array}{l}\text { federally- } \\
\text { funded }\end{array}$ & tuition-paying & $\begin{array}{l}\text { federally- } \\
\text { funded }\end{array}$ & $\begin{array}{l}\text { tuition- } \\
\text { paying }\end{array}$ \\
\hline Republic of Sakha (Yakutia) & 2918 & 2777 & 15633 & 6673 & 5.357 & 2.403 \\
\hline Kamchatka & 380 & 2340 & 1444 & 813 & 3.800 & 0.347 \\
\hline Primorye & 4020 & 5984 & 38849 & 10837 & 9.664 & 1.811 \\
\hline Khabarovsk region & 3125 & 7510 & 27053 & 12997 & 8.657 & 1.731 \\
\hline Amur region & 1672 & 4407 & 9145 & 2632 & 5.469 & 0.597 \\
\hline Magadan region & 315 & 703 & 1789 & 1127 & 5.679 & 1.603 \\
\hline Sakhalin & 514 & 1045 & 2074 & 1320 & 4.035 & 1.263 \\
\hline Jewish Autonomous District & 255 & 1130 & 1196 & 476 & 4.690 & 0.421 \\
\hline $\begin{array}{l}\text { Chukotka Autonomous } \\
\text { District }\end{array}$ & 37 & 31 & 73 & 43 & 1.973 & 1.387 \\
\hline Zabaikalye & 1648 & 4657 & 10049 & 5684 & 6.098 & 1.221 \\
\hline Republic of Buryatia & 2275 & 4325 & 11308 & 3864 & 4.971 & 0.893 \\
\hline Far Eastern Federal District & 17159 & 34909 & 118613 & 46466 & 6.913 & 1.331 \\
\hline
\end{tabular}

Lack of access to higher education in Far Eastern regions due to the shortage of study places 
Integral indicators of access to higher education in Far Eastern regions

\begin{tabular}{|c|c|c|}
\hline \multirow[b]{2}{*}{ Regions } & \multicolumn{2}{|c|}{ Access to higher education } \\
\hline & $\begin{array}{c}\text { federally- } \\
\text { funded places }\end{array}$ & $\begin{array}{l}\text { tuition-paying } \\
\text { places }\end{array}$ \\
\hline Chukotka Autonomous District & 1.03 & 1.19 \\
\hline Kamchatka & 0.68 & 1.89 \\
\hline Sakhalin & 0.66 & 1.33 \\
\hline Jewish Autonomous District & 0.54 & 1.40 \\
\hline Republic of Buryatia & 0.53 & 1.28 \\
\hline Republic of Sakha (Yakutia) & 0.52 & 0.89 \\
\hline Amur region & 0.50 & 1.51 \\
\hline Magadan region & 0.50 & 1.16 \\
\hline Zabaikalye & 0.45 & 1.13 \\
\hline Far Eastern Federal District & 0.42 & 1.17 \\
\hline Khabarovsk region & 0.34 & 1.04 \\
\hline Primorye & 0.31 & 1.02 \\
\hline
\end{tabular}

Khabarovsk and Primorye, while Chukotka demonstrated the highest value. In all these regions, accessibility to higher education is largely determined by the enrolment capacity of regional universities.

In terms of tuition-paying places, access to higher education is the lowest in the Republic of Sakha (Yakutia), where the application ratio is 2.4 applications per place. High values of this indicator are found in two regions - Amur and Kamchatka, where the number of applications is much smaller than the number of available tuition-paying places.

Concerning the contribution of each component to the overall higher education accessibility, a university's admission capacity and geography demonstrated the highest and smallest impact, respectively (see Fig. 1).

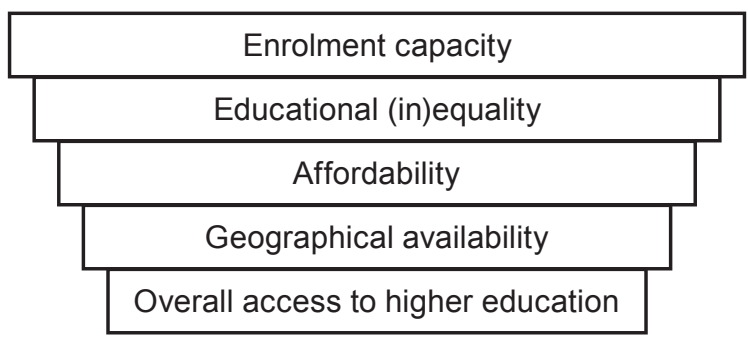

Fig. 1. Contribution of the key components to the overall access to higher education

It should be borne in mind, however, that all of these aspects are mutually interconnected; therefore, stimulation of a region's performance by enhancing only one aspect will have a limited effect. Thus, it becomes obvious that efforts aimed at facilitating access to higher education should target the whole range of components.

It is crucial that universities work together with federal and regional authorities to enhance access to higher education. Our analysis shows that access to higher education is a phenomenon shaped by multiple factors. Therefore, universities in the Russian Far East should apply various recruitment and admission strategies, as well as collaborate with federal and regional authorities to ensure the supply of qualified staff for local industries.

The proposed methodology can be adapted for the purposes of enhancing access to higher education in various regional education institutions, which can design and implement their own developmental policies. In turn, regional authorities can implement targeted social and economic programmes to improve access to higher education for the people from remote and rural areas, who are at a massive disadvantage in comparison with those who live in regional centres.

Our analysis of the geographical accessibility of higher education in the Far East shows that geography is a critically important factor, practically for all regions in this part of Russia (except for Primorye). This is explained by the territory's size and the concentration of universities in regional centres. The low level of geographical accessibility of higher education for inhabitants of the Russian Far East reduces the affordability of education, since families living far from universities and their branches need to cover travel, accommodation and living expenses for their children studying away from home.

Changes in the historically established distribution of universities and population across the territory of Russia and its regions caused the creation of new universities and branches in sparsely populated areas. Therefore, a viable solution may be to compensate for the low level of geographical accessibility of higher education in such areas through financial aid and benefits paid from the regional or university budget, for instance, by compensating students' travel, lodging and meals costs. This will reduce the financial burden on students' families, enhance education affordability and, consequently, improve the overall access to higher education.

Another type of financial aid could be offered to students staying in off-campus housing to cover the cost of renting an apartment. Many Russian universities are facing accommodation shortage problems, which makes education less affordable for students from remote towns and rural areas. Federal grants in the amount corresponding to expenses borne by 
universities for maintaining on-campus dormitory accommodation may be provided to students.

Federal and regional authorities need to set quotas regulating the number of federally-funded places for students choosing to study in the location of their family residence. The majority of universities are training specialists for their local industries. Therefore, the allocation of federally-funded places to specific universities and federal districts is determined by a region's perceived needs in certain kinds of specialists. From the standpoint of regional governments, it seems counter-productive to fill federally-funded places (which were allocated to train local specialists of certain expertise) with students from other regions, since such students are likely to return home after graduation.

Tuition policies also need to be revised; for instance, instead of setting the minimum tuition fee rates $^{4}$, only their upper limit may be determined in order to increase the affordability of higher education.

\section{Conclusion}

Access to higher education is a complex phenomenon determined by a range of factors, such as geography, affordability, admission capacity, as well as the level of educational inequality and inclusivity.

Our analysis demonstrates that people who live in the Russian Far Eastern regions enjoy substantial access to higher education services, particularly in terms of affordability, equality and inclusivity. The geographical factor, however, puts applicants from rural and remote areas located far from regional centres at a disadvantage, and has a detrimental effect on overall access to higher education in the Far East.

The proposed methodology can be used for measuring the level of higher education accessibility for specific universities and regions. Moreover, it can be used to identify problems that need to be tackled through specific measures and policies both at the level of individual universities, and at regional and federal levels.

In this context, it is clear that the joint efforts of universities and governments should be well-grounded and tailored to specific goals and situations. Such efforts will require a thorough quantitative analysis of the key components of higher education accessibility.

${ }^{4}$ For more detailed information on the basic standard costs of public service delivery in the sphere of education, science, youth policy, child custody and guardianship and the corresponding industry coefficients see: Decree of the Ministry of Education and Science of Russia of 20.06.2016 № 884. Accessed via the legal reference system 'ConsultantPlus'.

\section{References}

1. Bowes L., Thomas L., Peck L., Nathwani T. International Research on the Effectiveness of Widening Participation, available at: http://www.hefce.ac.uk/me$\mathrm{dia} /$ hefce/content/pubs/indirreports/2013/WP, international, research/2013_WPeffectiveness.pdf (accessed: 12.12.2018). (In Eng.).

2. Chowdry H., Crawford C., Goodman L., Deaden L., Vignoles A. «Widening Participation in Higher Education: Analysis Using Linked Administrative Data.», Journal of the Royal Statistical Society: Series A Statistics in Society, 2013, vol. 176, no 2, pp. 431-457. https://doi. org/10.1111/j.1467-985X.2012.01043.x (In Eng.).

3. Evans C., Rees G., Taylor Ch., Wright C. «Widening Access» to higher education: the reproduction of university hierarchies through policy enactment, Journal of Education Policy, 2019, vol. 34, no 1, pp. 101-116. https://doi.org/10.108 0/02680939.2017.1390165 (In Eng.).

4. Global Higher Education Rankings 2010. Affordability and Accessibility in Comparative Perspective, available at: http://ireg-observatory.org/pdf/HESA Global_Higher_EducationRankings2010.pdf (accessed: 15.01.2019). (In Eng.).

5. Education at a Glance 2018. OECD INDICATORS, available at: http://oecd.org'education/education-at-aglance/ (accessed: 12.08.2019). (In Eng.).

6. Klyuev A. S. Informacionnyj byulleten' «Monitoring regional'nyh problem dostupnosti vysshego obrazovaniya» [Information Bulletin «Monitoring of regional problems of accessibility of higher education»], Yekaterinburg, Publishing House of the Ural University, 2007, 143 p. (In Russ.).

7. Evseenko T. P. Dostupnost' vysshego obrazovaniya $v$ usloviyah formirovaniya rynka obrazovatel'nyh uslug [Accessibility of higher education in the context of the formation of the educational services market]. Economics of Education, 2007, no 3, pp. 114-132. (In Russ.).

8. Dostupnost' vysshego obrazovaniya. Sbornik statej. [Accessibility of higher education. Digest of articles], available at: https://kpfu.ru/staff_files/F560128183/sbornik_ novyi_2docx.pdf (accessed 02.02.2019). (In Russ.).

9. Ha Vang Hoang. Dostupnost' vysshego obrazovaniya v rossijskom i v'etnamskom obshchestvah: sravnitel'nyj analiz [Accessibility of Higher Education in Russian and Vietnamese Societies: A Comparative Analysis], Doctor's thesis, Penza, 2017, 194 p. (In Russ.).

10. Rahmanova M. S. Metodika ocenki dostupnosti vysshego obrazovaniya [Methodology for assessing the accessibility of higher education]. University Management: Practice and Analysis, 2014, no 6, pp. 110-117. (In Russ.).

11. Suhochev V. I. Dostupnost' vysshego obrazovaniya v usloviyah perekhoda k ekonomike znanij [Accessibility of higher education in the context of the transition to a knowledge economy]. Creative Economy, 2009, vol. 3, no 9, pp. 8-16. (In Russ.).

12. Anikina E. A., Lazarchuk E. V., Chechina V. I. Dostupnost' vysshego obrazovaniya kak social'no-ekonomicheskaya kategoriya [Accessibility of higher education as a socio-economic category]. Fundamental Research, 2014. no 12, pp. 355-358. (In Russ.). 
13. Klyachko T. L. Dostupnost' vysshego obrazovaniya: sostoyanie i perspektivy [Accessibility of higher education: state and prospects]. Public Education, 2005, no 10, pp. 44-56. (In Russ.).

14. Belyakov S. A. Modernizaciya obrazovaniya v Rossii: sovershenstvovanie upravleniya [Modernization of education in Russia: improving management], Moscow, MAKS Press, 2009, 437 p. (In Russ.).

15. Roshchina YA. M. Dostupnost' vysshego obrazovaniya: po sposobnostyam ili po dohodam? [Accessibility of higher education: by ability or by income?]. University Management: Practice and Analysis, 2005, no 1, pp. 69-79. (In Russ.).

16. Gromov A. D., Platonova D. P., Semenov D. S., Pyrova T. L. Dostupnost' vysshego obrazovaniya v regionah Rossii [Accessibility of higher education in the regions of Russia], Moscow, NIU VSHE, 2016, 32 p. (In Russ.).

17. Cullinan J., Flannery D., Walsh Sh., McCoy S. Distance Effects, Social Class and the Decision to Participate in Higher Education in Ireland, The Economic and Social Review, 2013, vol. 44, no 1, pp. 19-51. (In Eng.).

18. Verdis A., Kalogeropoulos K., Chalkias Ch. Regional disparities in access to higher education in Greece, Research in Comparative and International Education, 2019, vol. 14, no 2, pp. 318-335. https://doi.org/10.1177/1745499919846186 (In Eng.).

19. Blinova T. N., Fedotov A. V. Dostupnost' uslug vysshego obrazovaniya: ponyatie i metodiki ocenki [Accessibility of higher education services: concept and evaluation methods]. Management Consulting, 2018, no 12, pp. 128-141. (In Russ.).

20. Blinova T. N. Sovershenstvovanie upravleniya territorial'noj dostupnost'yu uslug vysshego obrazovaniya v Dal'nevostochnom federal'nom okruge [Improving the management of the territorial accessibility of higher education services in the Far Eastern Federal District]. Power and Administration in the East of Russia, 2018, no 4 (85), pp. 62-73. (In Russ.).

21. Suhochev V. I. Metodologiya formirovaniya organizacionno-ekonomicheskogo mekhanizma ocenki dostupnosti i kachestva vysshego obrazovaniya [The methodology of forming the organizational and economic mechanism for assessing the accessibility and quality of higher education], Doctor's thesis, Ufa, 2011, 404 p. (In Russ.).

22. Bhopal K.., Henderson H. Competing inequalities: gender versus race in higher education institutions in the UK, Educational Review, 2019, available at: https://www.tandfonline.com/doi/full/10.1080/00131911.2019.1642305 (accessed: 10.08.2019). https://doi.org/10.1080/00131911.2019.1642305

Submitted on 15.08.2019
(In Eng.).

23. Lee Y., R. M. Capraro, Bicer A. Gender difference on spatial visualization by college students' major types as STEM and non-STEM: a meta-analysis, International Journal of Mathematical Education in Science and Technology, 2019, available at: https://www.tandfonline.com/doi/full/10.1080/0 020739X.2019.1640398 (accessed: 10.08.2019). https://doi.org /10.1080/0020739X.2019.1640398 (In Eng.).

24. Findlay J., Hermannsson K. Social origin and the financial feasibility of going to university: the role of wage penalties and availability of funding, Studies in Higher Education, 2018, available at: https:/www.tandfonline.com/doi/fu 11/10.1080/03075079.2018.1488160 (accessed: 10.08.2019). https://doi.org/10.1080/03075079.2018.1488160 (In Eng.).

25. Netz N., Finger C. New Horizontal Inequalities in German Higher Education? Social Selectivity of Studying Abroad between 1991 and 2012, Sociology of Education, 2016, vol. 89, no. 2, pp. 79-98. (In Eng.).

26. Brewis E. Fair access to higher education and discourses of development: a policy analysis from Indonesia, Compare: A Journal of Comparative and International Education. 2019, vol. 49, issue 3, pp. 453-470. https://doi.org /10.1080/03057925.2018.1425132 (In Eng.).

27. Nieuwenhuis M., Manstead A. S. R., Easterbrook M. J. Accounting for unequal access to higher education: The role of social identity factors. Group Processes \& Intergroup Relations. 2019, vol. 22, № 3, pp. 371-389. (In Eng.).

28. Munk M. D, Thomsen J.-P. Horizontal stratification in access to Danish university programmes. Acta Sociologica. 2017, vol. 61, № 1, pp. 50-78. https://doi.org/10.1177/0001699 317694941 (In Eng.)

29. Mathew A. Balancing Social and Regional Equity: Higher Education Policy Trajectory in Kerala. Higher Education for the Future. 2019, vol. 6, № 2, pp. 207-225. https://doi.org/10.1177/2347631119857836 (In Eng.).

30. Jungblut J., Vukasovic M., Steinhardt I. Higher education policy dynamics in turbulent times - access to higher education for refugees in Europe. Studies in Higher Education. 2018, pp. 1-12. https://doi.org/10.1080/03075079.2018.15256 97 (In Eng.).

31. Glass Ch. R., Streitwieser B., Gopal A. Inequities of global mobility: socioeconomic stratification in the meanings of a university education for international students. Compare: A Journal of Comparative and International Education. 2019, pp. 1-18. https://doi.org/10.1080/03057925.2019.1590180 (In Eng.).

Accepted on 10.10.2019

\section{Information about authors:}

Tatiana N. Blinova - Associate Professor of the Department of Management and Business Law of the Far Eastern Institute of Management - a branch of the Russian Presidential Academy of National Economy and Public Administration, Russian Federation; Blinova-82@rambler.ru.

Aleksandr V. Fedotov - Dr. hab. (Economics), Professor, Leading Researcher, Russian Presidential Academy of National Economy and Public Administration; Russian Federation; fedotovfedotov@gmail.com. 